\title{
Prevalence of Hepatitis B Core Antibody in Medical Health care Workers in Nnewi, Anambra state, Nigeria
}

\author{
Onwurah O.W* ${ }^{1}$, Ezewenna E.C ${ }^{2}$, Anokwute M.U ${ }^{1}$, Ajuba I.C ${ }^{1}$, Ifeanyichukwu M² $^{2}$ Amilo G.I. ${ }^{2}$, \\ Ezeugwunne I.P \\ ${ }^{1}$ Department of Haematology, Nnamdi Azikiwe University Teaching Hospital, Nnewi, Anambra State, \\ Nigeria. \\ ${ }^{2}$ Department of Medical Laboratory Science, College of Health Sciences, Nnamdi Azikiwe University, \\ Nnewi-Campus, Anambra State - Nigeria. \\ ${ }^{3}$ Department of Human Biochemistry, Nnamdi Azikiwe University, Nnewi, Anambra State,Nigeria. \\ *Corresponding Author: Onwurah O.W, Department of Haematology, Nnamdi Azikiwe University \\ Teaching Hospital, Nnewi, Anambra State, Nigeria.
}

\begin{abstract}
Antibody to hepatitis $B$ core antigen ( $H B c A b)$ is the most sensitive marker of previous hepatitis $B$ contact. HBsAg infection is a serious global health issue, number of people have had the infection in the past without been aware. This study was aimed at finding the prevalence of HBcAb among the medical health care workers (MHCWs) in Nnamdi Azikiwe university teaching hospital (NAUTH) in Nnewi, south east Nigeria. One hundred (100) medical health care workers, comprising of 20 medical doctors, 20 medical laboratory scientists, 20 nurses, 20 theater attendants and 20 ward attendants were used for the study, using the HBV diagnostic panel kit (Diagnostic Automation/ Cortez Diagnostic Inc, USA). The result showed that $34 \%$ of the medical health care workers were positive for $H B c A b$, greater positive number were seen the females than the males. The non-vaccinated Medical Health care worker showed higher prevalence in positive $H B c A b$.
\end{abstract}

Keywords: HBcAb, Medical health care works, NAUTH, Nnewi.

\section{INTRODUCTION}

Hepatitis B virus (HBV) is a major causative agent of hepatocellular carcinoma (HCC) and it remains a major public health problem worldwide ${ }^{(1)}$. Viral hepatitis causes both acute and chronic infection with significant complications. Up to 400 million people worldwide have hepatitis B surface antigen (HBsAg)-positive chronic viral infection, which is primarily acquired by vertical transmission in high-endemicity countries ${ }^{(2)}$. HBV accounts annually for an estimated 1 million deaths worldwide ${ }^{(3)}$. Transmission of HBV among adults occurs via contact with infected blood and body fluids such as semen, vaginal fluids and salvia. Antibody to hepatitis B core antigen (anti-HBc or $\mathrm{HBcAb}$ ) is the most sensitive marker of previous hepatitis B contact ${ }^{(4)}$. It is the earliest antibody in response to $\mathrm{HBV}$ infection, appearing as $\mathrm{IgM}$ anti-HBc, and it persists for life as $\operatorname{IgG}$ anti-HBc after 6 months of the infection ${ }^{(5)}$. Isolation of anti-Hbc signify either remote infection with waning anti-HBs without viremia or infection with undetectable level of HBsAg. HVB infection is a serious global health issue, number of people have had the infection in the past, some are dead while some developed protective antibody which occur natuarally or through immunization. A Medical Health care worker (MHCW) was defined as an individual who works in a health facility providing healthcare services or involved in maintenance of the health facilities. Health workers that are at-risk are those that who often come in contact with blood and body fluids from patients they are caring for while in the hospital. These included doctors and nurses who treat patients, laboratory personnel involved in sample collection, staff who handles hospital waste and soiled laundry, and mortuary attendants who handle dead bodies. Health facility is defined as a registered place, private or public, that offered healthcare services. When infection of HBV occurs, there follows the development of host immunity, the nature determines the course and type of disease and its consequences; some will develop persistent 
Prevalence of Hepatitis B Core Antibody in Medical Health care Workers in Nnewi, Anambra state, Nigeria

HBsAg while others will clear the virus and become HBsAg-negative ${ }^{(6)}$. However, studies have shown that some HBsAg-negative individuals with $\mathrm{HBcAb}$ or circulating $\mathrm{HBV}$ DNA or both could remain infectious ${ }^{(7,8)}$ and continue to spread the infection through HBsAg-negative-anti-HBc positive donors . Anti-HBc is the first antibody produced after HBV infection and the only detectable marker in the window period. The isolation of anti- $\mathrm{HBc}$ in serum in the absence of HBsAg may be due to resolved $\mathrm{HBV}$ infection which $\mathrm{HBs}$ Ab becomes undetectable.

In Nigeria, the prevalence of $\mathrm{HBcAb}$ is $53.3 \%$ (9), and the HBV screening programs often test only HBsAg and $\mathrm{HBs}$, missing those individuals who have $\mathrm{HBcAb}$ as the only detectable marker ${ }^{(10)}$, hence this study will give us the prevalence of $\mathrm{HBcAb}$ in medical health care workers in Nnamdi Azikiwe University Teaching hospital (NAUTH), Nnewi, Anambra state, Nigeria.

\section{MATERIALS AND METHOD}

This is a cross sectional study to determine the prevalence of Hepatitis B core antibody in medical health workers in NAUTH, Nnewi. One hundred (100) medical health workers, comprising of 20 medical doctors, 20 medical laboratory scientists, 20 nurses, 20 theater attendants and 20 ward attendants were used for this study. Those vaccinated with Hepatitis antigen were 56 and those not vaccinated were 44. Two milliliters $(2 \mathrm{ml})$ of venous blood was collected from them into a clean plain sample bottle. The blood samples were allowed to clot and the serum collected for the analysis. The HBV diagnostic panel kit (Diagnostic Automation/ Cortez Diagnostic Inc, USA) for the qualitative detection of HBsAg, HBsAb, $\mathrm{HBeAg}, \mathrm{HBeAb}$ and $\mathrm{HBcAb}$ was used, applying the principle of two site sandwich method for HBsAg and HbsAb while using the principle of competitive inhibition method for $\mathrm{HBeAb}$ and HBcAb. Two drops of the serum sample were added into the five different sample wells and allowed to react for 15 minutes and the result read. The results were statistically analyzed using statistical package for social science, version 23 and expressed in as simple prevalence, using chi-square to determine the level of significance which is set at $95 \%(0.05)$ confidence interval.

\section{RESULT}

The result showed that out of the 100 samples that were studied, $34 \%$ were $\mathrm{HBcAg}$ positive and $66 \%$ were negative for both $\mathrm{HBsAg}$ and $\mathrm{HBcAb}$ testing (Figure 1).

The 34\% MHCWs that were positive for $\mathrm{HBcAb}, 35.3 \%$ (12) were male while $64.7 \%$ (22) were female. Chi-square ( $\chi^{2}$ ) was used to test the significant difference in the association between gender and $\mathrm{HBcAb}$ and the result showed that there exists no significant difference in the association between gender and $\mathrm{HBcAb}$ with $\chi^{2}=1.585, \mathrm{df}=1$ and $\mathrm{p}$-value $=$ 0.208 which is greater than 0.05 ( figure 2 ).

Among the healthcare workers that were $\mathrm{HBcAb}$ positive, $35.3 \%$ were theater attendants, $29.4 \%$ were nurses, $23.5 \%$ were ward attendants, $11.8 \%$ were Doctors, and none were positive among the scientists. $\chi^{2}$ used to test the significant difference in the association between Health care workers showed that there exists a significant difference in the association between health care workers and $\mathrm{HBcAb}$ with $\chi^{2}=$ $20.677, \mathrm{df}=4$ and $\mathrm{p}$-value $=0.000$ which is less than 0.05 (Figure 3).

The relation of the $\mathrm{HBcAb}$ positivity to Age were shown on figure 4 , the 4 Doctors that tested positive to $\mathrm{HBcAb}, 50 \%$ were males were as $50 \%$ were females, 10 Tested positive among Nurses had $100 \%$ of them to be females, 12 tested positive among Theater attendants, showed $66.7 \%$ were males and $33.3 \%$ were females. Out of the 8 ward attendants that tested positive, $25.0 \%$ were males and $75.0 \%$ were females.

In relation to age, the $34 \mathrm{HBcAb}$ positive health care workers showed that $41.2 \%$ were within the age of $25-30$ years, $29.4 \%$ were within age $31-35,23.5 \%$ are within age 36-40, whereas $5.9 \%$ are were 56 and not vaccinated were 44 within age 41-45 as shown in Figure 5.

Among the vaccinated medical health care workers, $4(11.8 \%)$ tested positive for $\mathrm{HBcAb}$; and $30(88.2 \%)$ of the non vaccinated medical health care workers were also positive for $\mathrm{HBcAb}$, as shown in Figure 6. 
Prevalence of Hepatitis B Core Antibody in Medical Health care Workers in Nnewi, Anambra state, Nigeria
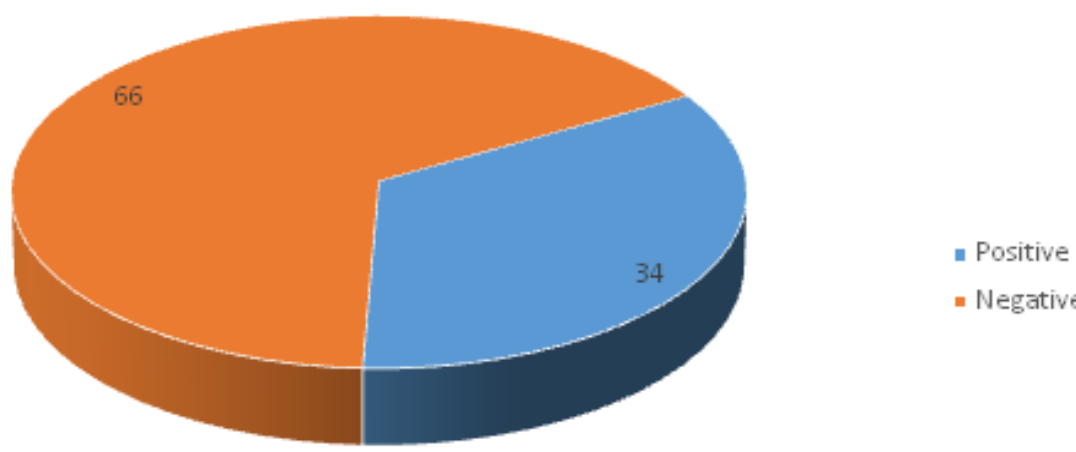

Fig1. HbcAb positivity among the medical health workers

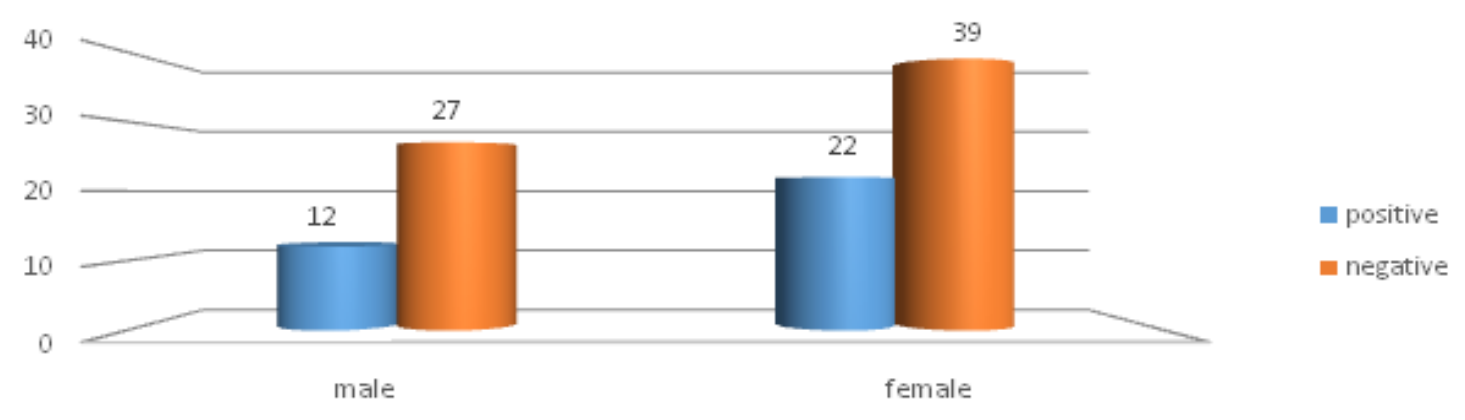

Fig2. HbcAb positive related to gender

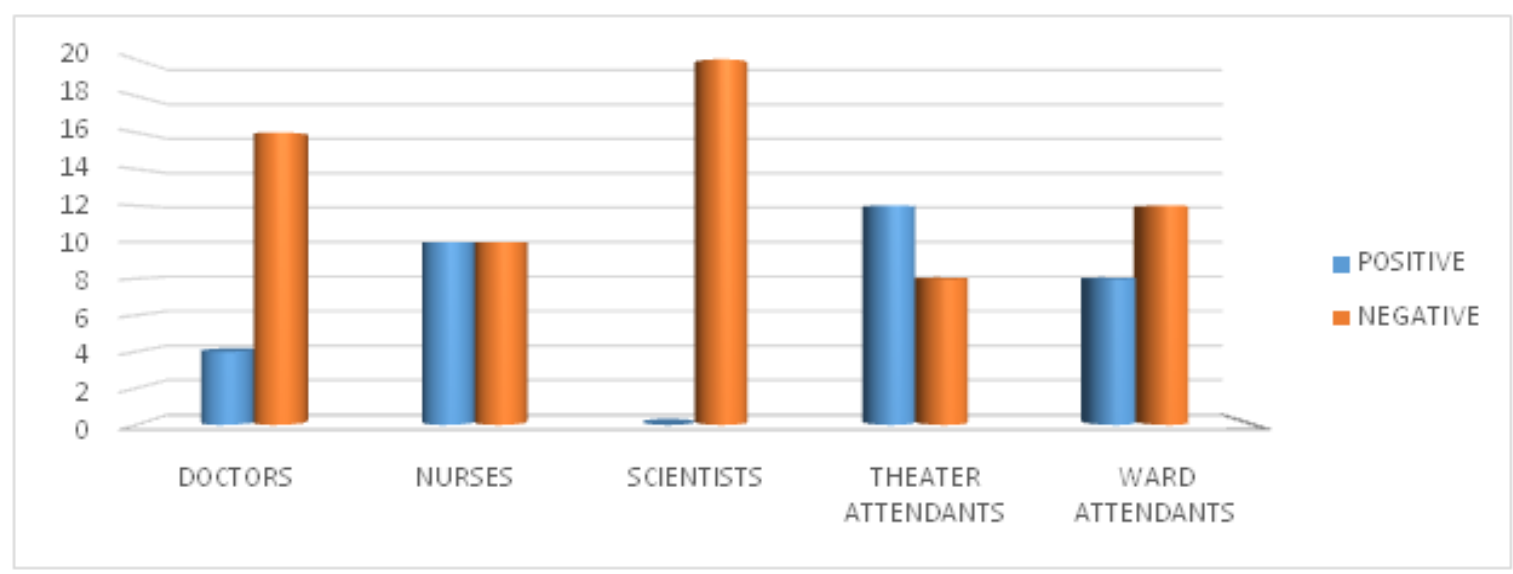

Fig3. HbcAb positivity in medical health care workers

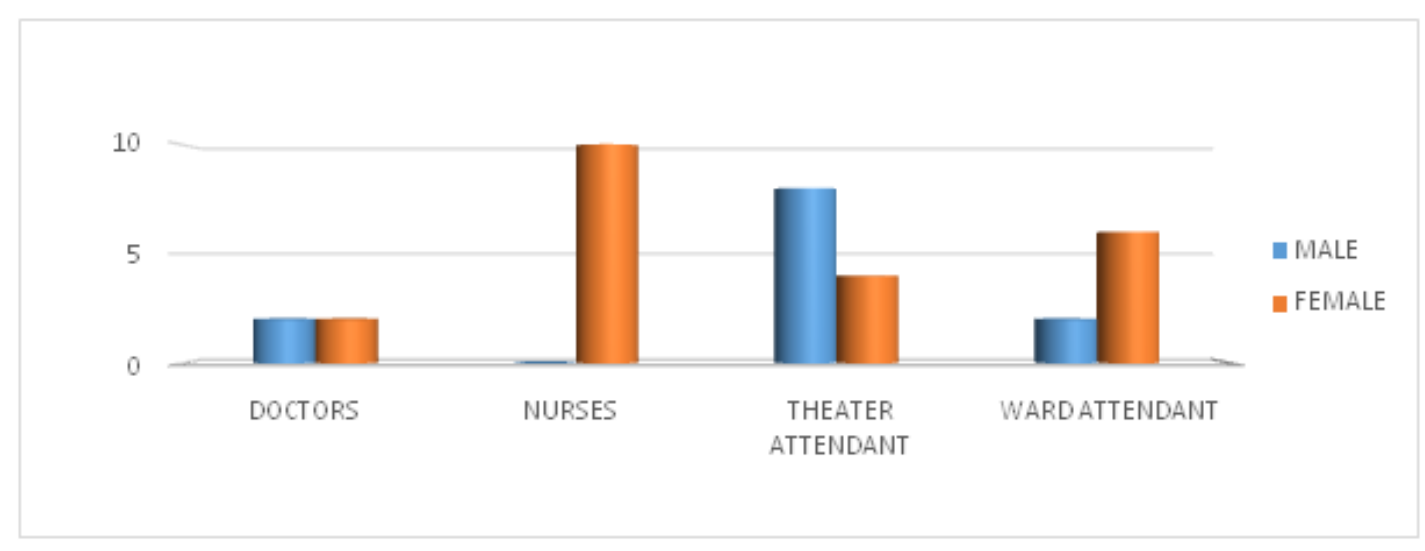

Fig4. HcAb positivity in different health care workers with relation to gender 
Prevalence of Hepatitis B Core Antibody in Medical Health care Workers in Nnewi, Anambra state, Nigeria

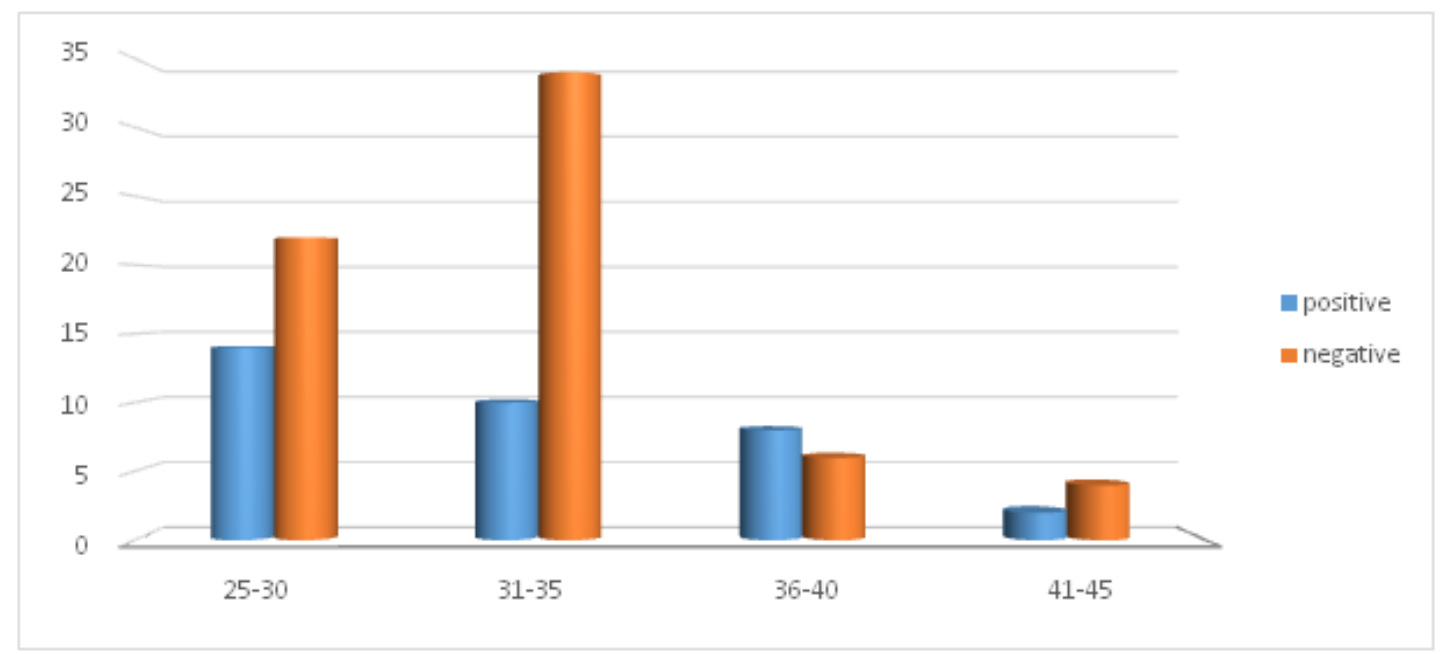

Fig5. HbcAb positivity in different medical health care worker in relation to Age

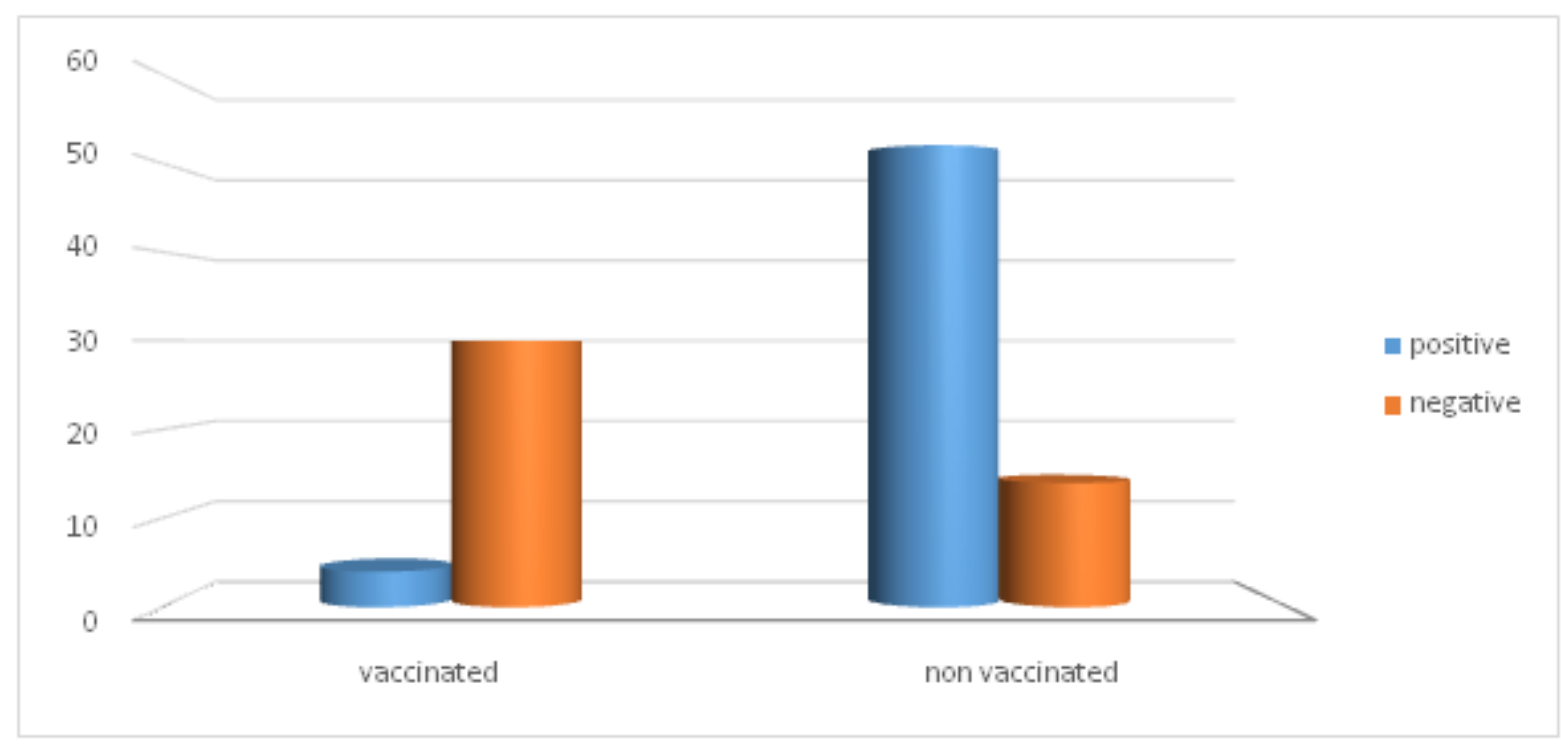

Fig6. HbcAb positive among vaccinated and non vaccinated health care workers

\section{DISCUSSION}

The main aim of the study is to investigate the prevalence of hepatitis B core antibody among Medical health care workers (MHCWs)

This study recorded $34 \quad(34.0 \%)$ medical healthcare worker in NAUTH positive with HB core antibody ( $\mathrm{HBcAb})$. The $34 \mathrm{MHCW}$ in our study who tested positive for $\mathrm{HBcAb}$ were all $\mathrm{HBsAg}$ negative. This is in accordance with other studies $^{(11,13,14)}$, who reported the presence of $\mathrm{HBcAb}$ in serologically silent $\mathrm{HBV}$ infection. The result obtained from this study was lower than the $70 \%$ that was recorded among health works in Albania ${ }^{(15)}$, and higher than the $1.6 \%$ obtained in Mexico ${ }^{(16)}$. Among MHCWs that were positive for $\mathrm{HBcAb}$, the theatre attendants had the highest prevalence of $12(35.3 \%)$, the nurses were $10(29.4 \%)$, the ward attendants were $8(23.5 \%)$, the doctors were $4(11.8 \%)$, and the zero prevalence was seen among the laboratory scientist. These figures are higher when compared with the prevalence among Polish surgeons (11.2\%) and nurses (16.5\%) surveyed in 2009 and also among MHCWs from the two largest clinical hospital in the capitalWarsaw (15.7\%) surveyed in $2015^{(17)}$. The positive HB core antibody seen among theatre attendants, the nurses and ward attendants, could be attributed as some of the challenges facing health care sector in Nigeria in terms of inadequate infrastructure and protecting equipments within our hospitals. This study recorded that out of the $56 \%$ of the studied group that had received hepatitis $\mathrm{B}$ virus vaccination, $11.8 \%$ of them had $\mathrm{HBcAb}$ in their serum, which might suggest naturally acquired immunity against HBV. Another possible explanation of this finding might be that some MHCWs were infected occupationally with $\mathrm{HBV}$ in the pre-vaccination era, or that they were not tested for the markers of a previous 
Prevalence of Hepatitis B Core Antibody in Medical Health care Workers in Nnewi, Anambra state, Nigeria

infection, such as anti-HBs and/or anti-HBc, before vaccination ${ }^{(16)}$.

The unvaccinated MHCWs with $88.8 \%$ positive for $\mathrm{HBcAb}$ indicate the possibility of a past infection of the hepatitis B virus (HBV).

\section{CONCLUSION}

The presence of antibody to the hepatitis B core antigen (anti-HBc) IgG in serum usually means a past infection of the hepatitis B virus (HBV). A relatively high sero prevalence of $\mathrm{HBcAb}$ was found in MHCWs in NAUTH, especially among theatre attendants and nurses. The study provides evidence of the protective effect of HBV vaccine, highlighting the need for universal vaccination of all MHCWs before they start their professional career. The high prevalence of $\mathrm{HBcAb}(11.8 \%)$ among previously vaccinated MHCWs might suggest naturally acquired immunity against HBV.

\section{ACKNOWLEDGMENTS}

I wish to acknowledge all the Medical health care workers in NAUTH who gave their blood samples for the study.

\section{REFERENCES}

[1] Shim J, Kim BH, Kim NH, Dong SH, Kim HJ, Chang YW, et al.( 2005). Clinical features of HBsAg- negative but anti-HBc-positive hepatocellular carcinoma in a hepatitis B virus endemic area. Gastroenterol Hepatol.; 20:746-751

[2] Nishikawa H, Osaki Y.( 2013). Clinical Significance of Occult Hepatitis B Infection in Progression of Liver Disease and Carcinogenesis. Journal of Cancer; 4(6):473480.

[3] WHO: (2017) Global health sector strategy on viral hepatitis 2016-2021 Retrieved June 1, 2019 from [http://www. who.int/hepatitis/ strategy 2016-2021/ghss-hep/en/].

[4] Byrd KK, Lu PJ, Murphy TV (2013) Hepatitis $B$ vaccination coverage among health-care personnel in the United States. Public Health Reports. 128(6):498-509.

[5] Emond J,Wachs ME, Amend WJ, Ascher NI, Bretan PN, et al. (2010). The risk of transmission of hepatitis B from $\mathrm{HBsAg}(-)$, $\mathrm{HBcAb}(+), \quad \mathrm{HBIgM}(-)$ organ donors. Transplantation 59(4): 230-234.

[6] Ganczak M, Dmytrzyk-Daniłów G, Korzeń M, Drozd-Dąbrowska M, Szych Z.(2016). Prevalence of HBV infection and knowledge of
Hepatitis B among patients attending primary care clinics in Poland. Journal of Community Health. 41(3):635-644.

[7] James L, Bailey, Balter P, Berns J, Butera E, (2001). Recommendations for preventing transmission of infections among chronic hemodialysis patients. Mobidity and MortalityWeekly Report. Centers for Disease Control and Prevention 50(5): 1-43.

[8] Rehermann B, Ferrari C, Pasquinelli C, Chisari FV (2003). The hepatitis B virus persists for decades after patient's recovery from acute hepatitis despite active maintenance of a cytotoxic T-lymphocyte response. National Medicine 2(10): 1104-1108.

[9] Emechebe GO, Emodi IJ, Ikefuna AN, Ilechukwu GC, Igwe WC, Ejiofor OS. (2009). Hepatitis B virus infection in Nigeria - A review. Nigerian Medical Journal;50:18-22.

[10] Ryu W (2017). Molecular Virology of Human Pathogenic Viruses. Academic Press. pp. $247-$ 260.

[11] De Schryver A, Claesen B, Meheus A, van Sprundel M, François G.(2011). European survey on hepatitis B vaccination policies for health care workers. European Journal of Public Health.21(3):338-343.

[12] Byrd KK, Lu PJ, Murphy TV (2013) Hepatitis $B$ vaccination coverage among health-care personnel in the United States. Public Health Reports. 128(6):498-509.

[13] Coppola N, De Pascalis S, Onorato L et al (2016). Hepatitis B virus and hepatitis C virus infection in healthcare workers. World Journal of Hepatology;8:273-281.

[14] Kondili LA, Ulqinaku D, Hajdini M, Basho M, Chionne P, Madonna E, Taliani G, Candido A, Dentico P, Bino S, Rapicetta M. (2007). Hepatitis B virus infection in health care workers in Albania: a country still highly endemic for HBV infection. Infection. 35(2): 94-97.

[15] Méndez-Sánchez N, Motola-Kuba D, ZamoraValdés D, Sánchez-Lara K, PoncianoRodríguez G, Uribe-Ramos MH, VásquezFernández F, Lezama-Mora J, Pérez-Sosa JA,Baptista-González HA, Uribe M.(2006). Risk factors and prevalence of hepatitis virus B and $\mathrm{C}$ serum markers among nurses at a tertiary-care hospital in Mexico City, Mexico: a study. Annals of Hepatology. 5(4):276-280.

[16] Song LW , Liu PG, Liu CJ (2015) Quantitative hepatitis B core antibody levels in the natural history of hepatitis B virus infection . Clinical Microbiology Infection 21:197 - 203 
Prevalence of Hepatitis B Core Antibody in Medical Health care Workers in Nnewi, Anambra state, Nigeria

[17] Ganczak M, Dmytrzyk-Daniłów G, Korzeń M, Drozd-Dąbrowska M, Szych Z.(2016). Prevalence of HBV infection and knowledge of
Hepatitis B among patients attending primary care clinics in Poland. Journal of Community Health. 41(3):635-644.

Citation: Onwurah O.W et.al, "Prevalence of Hepatitis B Core Antibody in Medical Health care Workers in Nnewi, Anambra state, Nigeria”, International Journal of Research Studies in Medical and Health Sciences. 2020; 5(12): 27-32.

Copyright: (C) 2020 Onwurah O.W et.al, This is an open-access article distributed under the terms of the Creative Commons Attribution License, which permits unrestricted use, distribution, and reproduction in any medium, provided the original author and source are credited. 